\title{
Cystic schwannoma of the distal forearm. Case presentation
}

\author{
Valeriu Ardeleanu ${ }^{1}$, Daniel Pirici ${ }^{2}$, AnCa SAVA ${ }^{3,4)}$, Roxana Folescu ${ }^{5}$, \\ ANDREI GHEORGHE MARIUS MOTOC ${ }^{5}$ ) \\ 1) Department of Anatomy, Faculty of Medicine, Lower Danube University of Galati, Romania \\ 2) Department of Histology, University of Medicine and Pharmacy of Craiova, Romania \\ 3) Department of Morpho-Functional Sciences I, Grigore T. Popa University of Medicine and Pharmacy, Iaşi, Romania \\ 4) Department of Pathology, Prof. Dr. Nicolae Oblu Emergency Clinical Hospital, Iaşi, Romania \\ 5) Department of Anatomy and Embryology, Victor Babeş University of Medicine and Pharmacy, Timişoara, Romania
}

\begin{abstract}
Schwannomas are well-encapsulated, benign tumors arising from Schwann cell constituting the nerve sheaths. We report a case of a cystic conventional schwannoma, measuring $2.5 \times 3 \mathrm{~cm}$, located in the distal forearm of a 33-year-old female patient with no sign of neurofibromatosis type 2 or type 3 . The mass was painless, but Tinel's sign was positive. Ultrasonography showed a soft tissue cystic mass diagnosed as being synovial cyst in the left distal forearm. Surgical resection was performed without any complications. Histopathological examinations oriented the diagnosis to a schwannoma, but immunohistochemical stainings proved the tumor origin in Schwann cells and made the differential diagnosis with other pathologies, like neurofibroma, leiomyoma, epithelial cyst, synovial cyst, or ganglion cyst.
\end{abstract}

Keywords: cystic schwannoma, forearm, immunohistochemistry.

\section{口 Introduction}

Schwannomas are well-encapsulated, benign tumors arising from Schwann cells that constitute the nerve sheaths [1]. These tumors can develop from both somatic and autonomic nerves. The World Health Organization (WHO) Classification of CNS Tumors, established in 2016, included schwannomas in the category of "Tumours of the cranial and paraspinal nerves", along with neurofibroma, perineurioma, hybrid nerve sheath tumors, and malignant peripheral nerve sheath tumor (MPNST) [2]. These slow-growing tumors often have no symptoms in their first years of development, but later in their evolution signs of neural compression could develop, causing pain and sensory or motor deficits.

Macroscopically, these tumors can be round, oval, or plexiform [3], being colored in yellow or grey [4]. Unlike neurofibromas, schwannomas may have cystic areas of hemorrhagic degenerescence and necrosis. However, cystic schwannomas are extremely rare.

Cystic schwannomas are always difficult to diagnose because they can be mistaken for other tumors, such as synovial cyst, hydatid cyst, ganglion cyst, etc. [5].

Preferred treatment consists in surgical excision of the tumor without damaging the affected nerve. The complications that have been reported are temporary and mainly consist in sensory and motor deficits.

Schwannomas are generally resistant to radiotherapy. However, radiotherapy can be used as palliative treatment if the tumor is inoperable. However, even though schwannomas can recur after apparent total excision [6], fortunately, their malignant change is a very rare event.

\section{Aim}

This paper reports a case of a young woman, who presented a left distal forearm cystic lesion that clinically and by ultrasonography (US) was considered to be a synovial cyst, but histopathological (HP) and immunohistochemical (IHC) exams established the diagnosis of a conventional cystic schwannoma. We review the literature and discuss the management of this lesion.

\section{ㄷ Case presentation}

A female patient, aged 33, was admitted in the Department of Plastic Surgery, Aresthetic Clinic, Galaţi, Romania, for a progressively enlarging swelling of the left distal forearm. Systemic physical examination was normal, but the distal part of the left forearm presented a $2.5 \times 3 \mathrm{~cm}$, firm, well-delimited, non-pulsatile, and nonpainful mass.

The lesion was superficially located, mobile on superjacent and subjacent planes, renitent on palpation and painful to compression. A soft tissue US diagnosed the lesion as being a synovial cyst.

As the location was not a typical one for a synovial cyst, and the mass caused a certain degree of discomfort, surgical removal was decided. A longitudinal incision of about $3 \mathrm{~cm}$ was made under local anesthesia. The antebrachial fascia was dissected revealing a $2.5 \times 3 \mathrm{~cm}$, welldefined, white-greyish cystic tumor. Macroscopically, no nervous point of origin was detected. Tumor ablation was carried out, followed by hemostasis and suture. The tumor contained inside a viscous, translucent fluid similar to a synovial cyst. The tumor membrane was thicker and

This is an open-access article distributed under the terms of a Creative Commons Attribution-NonCommercial-ShareAlike 4.0 International Public License, which permits unrestricted use, adaptation, distribution and reproduction in any medium, non-commercially, provided the new creations are licensed under identical terms as the original work and the original work is properly cited. 
regular. The tumor ruptured upon extraction and the inner fluid was evacuated.

\section{Pathological description}

As preoperative and intraoperative diagnosis was uncertain, the surgical sample was sent to the Laboratory of Pathology. The tissue fragment was fixed in $10 \%$ neutral buffered formalin, then processed for paraffin embedding, sectioning and routine staining for Hematoxylin-Eosin (HE), as well as for immunohistochemistry.

For immunohistochemistry, the tissue sections were deparaffinated, rehydrated, processed for antigen retrieval by boiling in citrate buffer $\mathrm{pH} 6$ for 21 minutes, then the endogenous peroxidase was quenched with $0.1 \%$ hydrogen peroxide for 30 minutes and the unspecific antigenic situses were blocked with $3 \%$ skimmed milk. The first primary antibodies were incubated on consecutive slides for 18 hours, at $4^{\circ} \mathrm{C}$ (Table 1), then, the next day, the sections have been thoroughly washed in phosphatebuffered saline, and a peroxidase-conjugated species-specific secondary antibody (Vector Laboratories, Burlingame, CA, USA) was added on the slides for one hour at room temperature. After washing again, the signal was developed with 3,3'-Diaminobenzidine (DAB) (Vector Laboratories) and, finally, the slides have been lightly counterstained with Hematoxylin and coverslipped with a xylene-based mounting medium (Sigma-Aldrich, St. Louis, MO, USA). Slides were visualized and images acquired on a Nikon 90i motorized microscope equipped with a DS-Ri2 $16 \mathrm{MP}$ complementary metal oxide semiconductor (CMOS) camera and the Nikon NIS Elements AR software package.

Table 1 - The antibodies utilized in this study

\begin{tabular}{|c|c|c|c|}
\hline Name & Clone & Target & Dilution \\
\hline$\alpha-S M A$ & $1 \mathrm{~A} 4$ & Smooth muscle actin & $1: 100$ \\
\hline CK AE1/AE3 & AE1/AE3 & Pancytokeratin & $1: 100$ \\
\hline CD31 & JC70A & $\begin{array}{l}\text { Endothelial and tumor } \\
\text { cells }\end{array}$ & $1: 100$ \\
\hline CD45 & $\begin{array}{l}\text { 2B11+ } \\
\text { PD7/26 }\end{array}$ & Inflammatory cells & $1: 100$ \\
\hline GFAP & Polyclonal & Glial cells & $1: 20000$ \\
\hline Neurofilaments & $2 \mathrm{~F} 11$ & $\begin{array}{c}\text { Nervous tissue } \\
\text { intermediate filaments }\end{array}$ & $1: 100$ \\
\hline S100 protein & Polyclonal & $\begin{array}{l}\text { Intracellular } \mathrm{Ca}^{2+} \\
\text { binding proteins }\end{array}$ & $1: 1000$ \\
\hline Vimentin & V9 & Intermediate filaments & $1: 100$ \\
\hline
\end{tabular}

a-SMA: Alpha-smooth muscle actin; CD: Cluster of differentiation; CK Cytokeratin; GFAP: Glial fibrillary acidic protein. All primary antibodies produced by Dako Cytomation, Glostrup, Denmark.

On microscopy, the tumor was well-delimited by a fibrous capsule and exhibited a biphasic pattern, being composed of dense spindle-like cellular areas and hypocellular regions. Tumor cells from hypercellular regions were elongated, with indiscernible cell cytoplasm and with wavy nuclei. There was no nuclear atypia and mitoses, and no necrotic areas. Often, hypercellular areas showed nuclear palisading around a pink fibrillary material (Verocay bodies) (Figure 1, A and B). A dense collagen stroma was identified along with rare tortuous and compressed blood vessels lumina. No obvious inflammatory infiltrate could be identified within the tumor. HP examination suggested the diagnostic of a conventional cystic schwannoma.

IHC stainings revealed that the tumor cells were strongly positive for antibodies against the $\mathrm{S} 100$ protein and vimentin (Figures 1, C-F), thus proving their origin in Schwann cells. Because the tumor cells were negative for antibodies against neurofilaments and glial fibrillary acidic protein (GFAP), we could exclude a neurofibroma. Moreover, the tumor cells were completely negative to an anti-alpha-smooth muscle actin ( $\alpha$-SMA) antibody (Figure 2A), thus excluding a leiomyoma. Only extremely rare inflammatory cells interspersed between the tumor cells could be detected in the tumor stroma (Figure 2B). Anti-cluster of differentiation 34 (CD34) antibody detected endothelial cells of intratumoral vessels and only very rare tumor cells with no obvious lumina could be noted (Figure 2, C and D). Together with the negative reactivity for neurofilaments, this immunostaining was also useful for excluding a neuroma. The non-malignant nature was obvious, and an anti-pancytokeratin antibody (AE1/AE3) also showed no reactivity, thus excluding the presence of any epithelial component.

The final pathological diagnosis was that of a conventional cystic schwannoma, WHO grade I.

From a clinical point of view, because the patient had no family history of schwannoma or any other visible body tumors suggesting the existence of multiple schwannomas, we considered it to be a sporadic schwannoma and not related with neurofibromatosis type 2 (NF2) or neurofibromatosis type 3 (NF3, schwannomatosis).

Postoperative evolution was favorable, without any complications. Ten months after surgery, the wound was healed, and the patient did not have any sign of localized neurological dysfunction.

\section{ㅁ Discussions}

In 1910, José Verocay (1876-1927), a Uruguayan pathologist, who was working in Charles-Ferdinand University in Prague, described for the first time the morphological features which we now called "the Verocay bodies", which represent the hallmark of this tumor. Thus, the Uruguayan pathologist established schwannoma as a pathological entity [7]. Verocay considered that the tumor origin was the fibrous sheath of the nerve and as such he introduced the term "neurinoma", i.e., a tumor of the nerve. Some years later, as histopathology became a developed medical field, pathologists understood that fibroblast was not the cell of the origin for this nerve tumor. Stout, in 1935, highlighted the fact that this neoplasia has a neuroectodermal origin and named it as "neurilemmoma" [8].

The term "schwannoma", as we used today to denominate these tumors, was first coined by Ehrlich \& Martin, in 1943 [9].

After the 1960s, as electron microscopy and lately IHC techniques began to develop, Schwannian origin could be proven. In particular, the immunopositivity of tumor cells to the anti-S100 protein antibody provides a very valuable diagnostic tool. From a HP point of view, the schwannoma is characterized by two distinct morphological aspects: Antoni-A and Antoni-B, named after the Swedish neurologist who first described them, Nils Ragnar Eugène Antoni (1887-1968). He is the first to describe the two distinct aspects of cellular architecture 
in schwannomas. Antoni analyzed 30 cases of peripheral nerve tumors and noted the presence of a hypercellular tissue, which he called "tissue A", later called "Antoni-A" area, along with areas with a microcystic appearance, apparently distinct from "Antoni-A" regions, which he called "tissue B", later called "Antoni-B" areas. This histological description soon became useful in the microscopic identification of schwannomas [10].
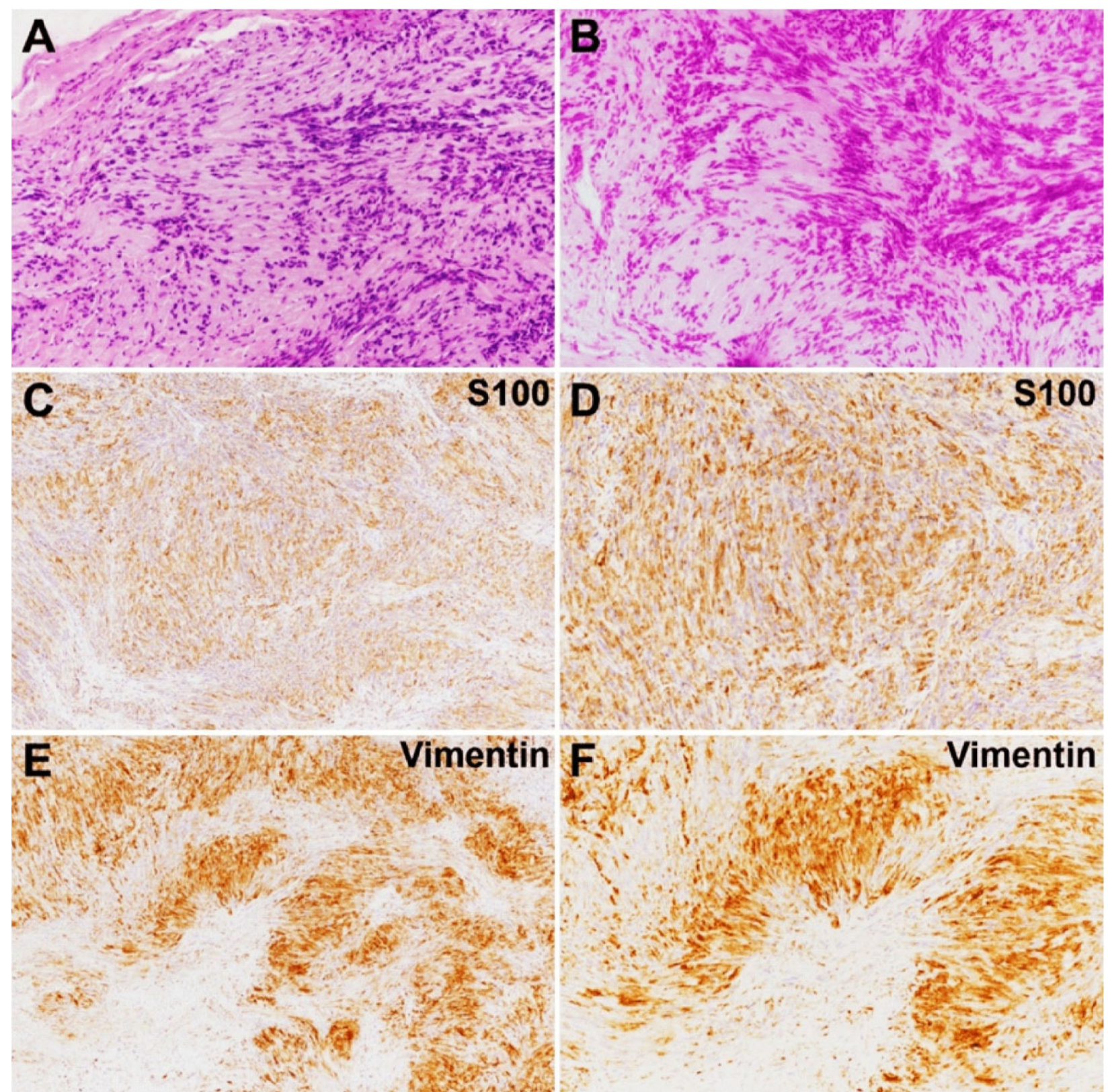

Figure 1 - Histopathology and immunohistochemical features of the tumor showed a biphasic pattern with alternating dense and hypocellular areas $(A)$, occasionally with nuclear palisading in the hypercellular regions (A and B). The tumor cells showed a strong immunoreactivity for anti-S100 $(C$ and $D)$ and anti-vimentin $(E$ and $F)$ antibodies. Hematoxylin-Eosin (HE) staining: $(A) \times 100 ;(B) \times 200$. Anti-S100 antibody immunomarking: $(C) \times 100 ;(D) \times 400$. Anti-vimentin antibody immunomarking: $(E) \times 100 ;(F) \times 400$.

The Antoni-A areas are made up of compact spindle cells with indistinct cell boundaries and wavy nuclei. In some areas, tumor nuclei can be arranged in parallel rows separated by pink fibrillary material, and this feature is called "nuclear palisading" or "Verocay bodies". Antoni-B areas are less cellular and lacks distinctive architectural features. The tumor stroma contains sparse collagen fibers, numerous blood vessels, which can often have a hyaline deposition in their walls. Foci of inflammatory cells including histiocytes may be present [2].

Schwannomas are the most common benign tumors of the peripheral nerves, representing $90 \%$ of all tumors developing in this anatomical structure and less than $8 \%$ of all benign soft-tissue tumors [11].

This neoplasia can affect patients aged between 20 and 70 years [4], but some authors reported even more extended age interval for the patients diagnosed with such tumors, i.e., 11 to 80 years [12]. Men and women are equally affected [13].

These tumors can develop from the spinal nerves, representing about one third of all benign spinal tumors, from the cranial nerves, especially the acoustic-vestibular $\left(\mathrm{VIII}^{\text {th }}\right)$ nerve, which is also the commonest central location of schwannomas [14], but also in the mandible, from the 
$\mathrm{V}^{\text {th }}$ nerve [15], or in the orbit, from sensory branches of the ophthalmic division of the trigeminal nerve, but also from the $\mathrm{II}^{\text {nd }}, \mathrm{III}^{\mathrm{rd}}, \mathrm{IV}^{\text {th }}$, and $\mathrm{VI}^{\text {th }}$ nerves [16-18]. Rare location of a schwannoma could be the parapharyngeal space, when the tumor origin is the $\mathrm{X}^{\text {th }}$ nerve, or vagus nerve [19].

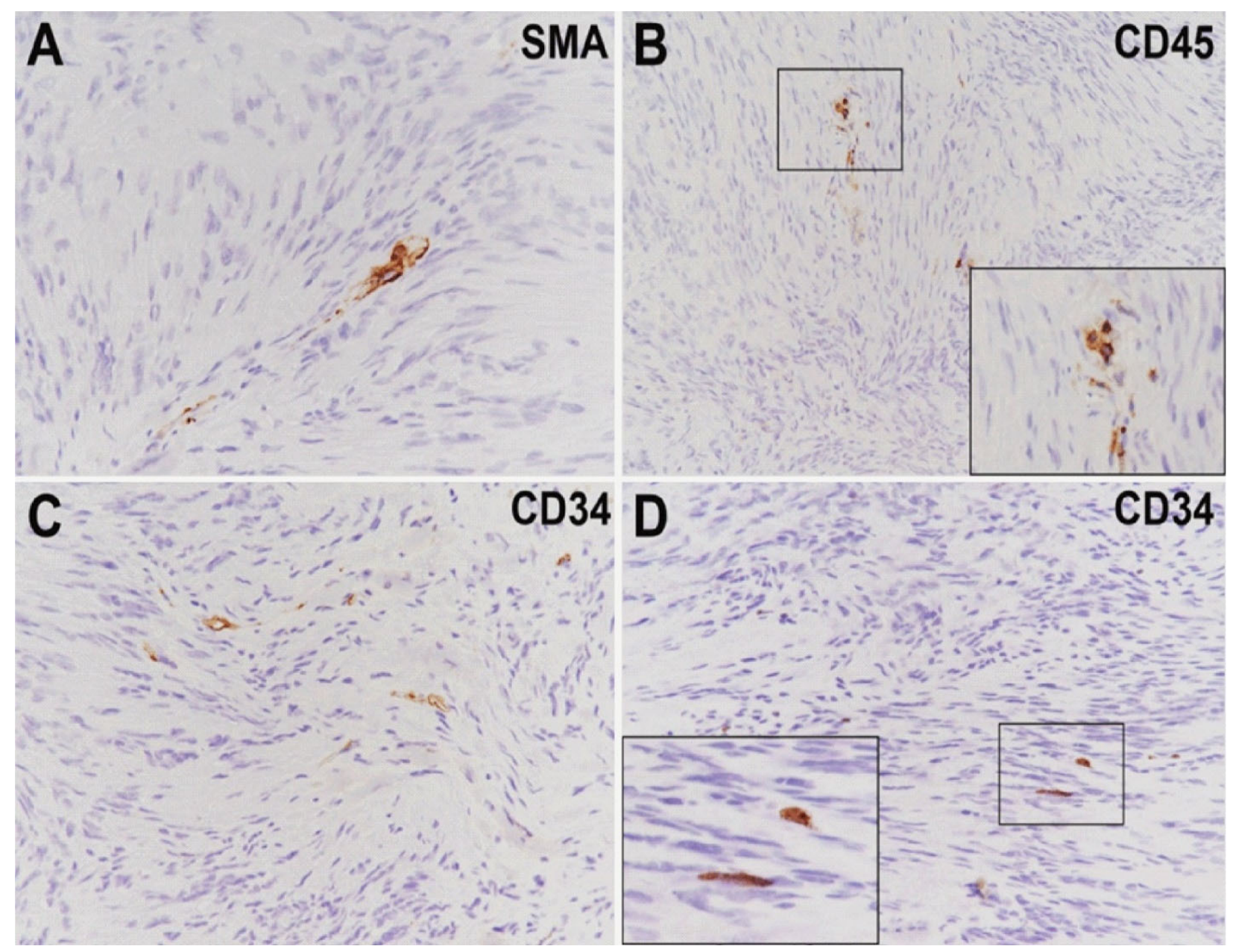

Figure 2 - Immunohistochemical features of the tumor (continuation) revealed no positivity for an anti- $\alpha$-SMA antibody $(A)$, only very rare inflammatory cells (B, identified by an anti-CD45 antibody), while an antibody for CD34 identified rare, abutted blood vessels and only very rare positive cells $(C$ and $D)$. Each inset represents the enlarged areas in the respective image. Anti- $\alpha-S M A$ antibody immunomarking: $(A) \times 400$. Anti-CD45 antibody immunomarking: $(B) \times 200$. AntiCD34 antibody immunomarking: (C and D) $\times 400$. a-SMA: Alpha-smooth muscle actin; CD: Cluster of differentiation.

Schwannomas may have other different locations, too. They can be located at the head, neck, mediastinum, retroperitoneum, pelvis, or limbs levels [20-22]. Even the pancreas could be the site for a schwannoma development [23]. Nineteen percent of all schwannomas are located at the extremities of the upper limbs [4].

Regarding their location in the upper limbs, schwannomas can be classified into proximal tumors, i.e., those involving the brachial plexus and the nerves of the arm, and distal tumors, i.e., involving the nerves of the forearm and the hand [24-26].

When located in the forearm, schwannoma may usually involve the cubital nerve; in less than $7 \%$ of these cases, the tumors are located along the nerve sheath of the median nerve, but they can also involve the radial nerve [23].

In exceptional cases, all three large nerves of the upper limb can be affected [22], making surgery much more difficult, but preoperative diagnosis becomes much easier.

Adani et al. analyzed 34 patients presenting schwannoma in the upper limbs. They reported that the tumor had its origin mostly in the ulnar nerve almost $(50 \%)$, in the median nerve $(25 \%)$, but only rare in the radial nerve, the anterior interosseous nerve, the musclecutaneous nerve, and the digital nerves [26].

Schwannomas of the upper limbs are generally solid tumors, sometimes plexiform, but more seldom are cystic tumors and this feature was the particularity of the presented case. They can also be located in the dermis, when they develop subcutaneously, and they can be multiple, similar to NF2.

The main differential diagnosis includes synovial cyst, ganglion cyst, neurofibroma, low-flow venous malformations, lymphangioma, intramuscular myxoma or highgrade sarcomas, such as fibrosarcoma, leiomyosarcoma or synovial sarcoma [4, 27, 28].

Schwannomas can be sporadic or hereditary, being assimilated to neurofibromas. The most important discovery for NF2 is the presence of bilateral vestibular schwannomas, which developed from the Schwann cells of VIII ${ }^{\text {th }}$ cranial nerve. Also, in 1973, Nimura reported the development of multiple schwannomas in the same person. The tumors were located along the cranial, spinal, and peripheral nerves, but not along the vestibular nerves, which is a characteristic of NF2 [29]. 
Schwannomatosis or NF3 is distinct from other NF forms and can be inherited in a predominantly autosomal model. In 2007, Hulsebos et al. reported a regulator of chromatin subfamily B member 1 (SMARCB1) constitutional mutation in a family affected by schwannomatosis [27, 30]. Trăistaru et al. also published a 63-year-old woman with multiple schwannomas located on ulnar nerve and superficial fibular nerve and emphasized on genetic analysis in order to identify a schwannomatosis, especially in cases with no known relatives with schwannomatosis [31].

Strikingly different from schwannomatosis, sporadic schwannomas are usually single tumors with a diameter between 1.5 and $3 \mathrm{~cm}$, rarely larger [4].

Clinical signs and radiology can be similar to those of other soft tissue tumors, making schwannomas easy to be preoperatively mistaken for other tumors.

Intraoperative findings and microscopy, together with IHC exams could help in defining the diagnosis of schwannomas. These tumors may have two clinical forms: an asymptomatic form, when the tumor looks like a painless swelling and is discovered accidentally, and the symptomatic form, which presents symptoms triggered by the compression of the surrounding structures, such as neurogenic pain in the extremities, local swelling, paresthesia, and motor impairment.

Clinical diagnosis may be suggested by the Tinel's sign [6], which should be integrated in the clinical picture. US may be useful, but most often it points to other disorders, as it did in our case. Magnetic resonance imaging (MRI) may represent a useful preoperative diagnosis method because schwannomas have an intermediate muscle intensity in the T1-weighted images and appear as hyperintense lesions in T2-weighted images.

For a more accurate preoperative diagnosis, ultrasoundguided needle biopsy is recommended. In our case, as preoperative US did not reveal either a schwannoma or the possible contact of the tumor with a nerve, as well as the unspecific symptoms and the scarcity of symptoms, we did not consider MRI of ultrasound-guided needle biopsy necessary.

The surgical treatment is an elective treatment for this tumor, but it is not always possible to enucleate it and to maintain nervous continuity, because sometimes the tumor may contain some nervous fibers inside its structure [28]. However, postoperatively, approximately one-fifth of patients may experience either tumor recurrence or severe neurogenic pain or newly developed motor deficits [32].

In cases with paralysis after excision of a forearm schwannoma, a neurorehabilitation program is required, which should be based on a neurodynamic mobilization in order to improve the postoperatively disfunction of the affected upper limb [33].

\section{ㅁ Conclusions}

When a patient presents in a surgery department with a palpable tumor located in the upper limb, the possibility of a schwannoma should be considered. For this reason, the clinician should look for the typical signs of schwannomas, such as the Tinel's sign. However, the final diagnosis should be the HP exam of the surgical specimen that should be completed with IHC stainings as in region of the distal forearm different pathological entities could develop.

\section{Conflict of interests}

Authors declare no conflict of interests.

\section{References}

[1] Kho JPY, Prepageran N. Huge brachial plexus schwannoma, masking as a cystic neck mass. AME Case Rep, 2018, 2:41. https://doi.org/10.21037/acr.2018.08.01 PMID: 30363802 PMCID: PMC6182036

[2] Louis DN, Ohgaki H, Wiestler OD, Cavenee WK. Tumors of the cranial and paraspinal nerves. In: Louis DN, Ohgaki $\mathrm{H}$, Wiestler OD, Cavenee WK (eds). WHO classification of tumours of the central nervous system. Revised $4^{\text {th }}$ edition, International Agency for Research on Cancer (IARC) Press, Lyon, France, 2016, 213-230.

[3] Katsumi K, Ogose A, Hotta T, Hatano H, Kawashima H, Umezu H, Endo N. Plexiform schwannoma of the forearm. Skeletal Radiol, 2003, 32(12):719-723. https://doi.org/10.10 07/s00256-003-0701-6 PMID: 14593503

[4] Dusad T, Meena DS, Saini N, Sharma Y, Khurana D. Schwannoma of the median nerve at mid forearm level. J Orthop Case Rep, 2016, 6(2):66-68. https://doi.org/10.13 107/jocr.2250-0685.438 PMID: 27703941 PMCID: PMC 5040577

[5] Lee SJ, Yoon ST. Ultrasonographic and clinical characteristics of schwannoma of the hand. Clin Orthop Surg, 2017, 9(1):9195. https://doi.org/10.4055/cios.2017.9.1.91 PMID: 28261433 PMCID: PMC5334033

[6] Knight DMA, Birch R, Pringle J. Benign solitary schwannomas: a review of 234 cases. J Bone Joint Surg Br, 2007, 89(3):382387. https://doi.org/10.1302/0301-620X.89B3.18123 PMID: 17356155

[7] Bologna-Molina R, Vigil-Bastitta G, Pereira-Prado V, ElolaVerocay L. Jose Verocay - "Prague's pathologist". The history of a Latin-American doctor. Cesk Patol, 2018, 54(3):147-150. PMID: 30445820

[8] Tonn JC, Westphal M, Rutka JT (eds). Oncology of CNS tumors. $2^{\text {nd }}$ edition, Springer-Verlag, Berlin-Heidelberg-DordrechtLondon-New York, 2010, 752. https://doi.org/10.1007/9783-642-02874-8

[9] Ehrlich HE, Martin H. Schwannomas (neurilemmomas) in the head and neck. Surg Gynecol Obstet, 1943, 76:577-583.

[10] Wippold FJ 2nd, Lubner M, Perrin RJ, Lämmle M, Perry A. Neuropathology for the neuroradiologist: Antoni A and Antoni B tissue patterns. AJNR Am J Neuroradiol, 2007, 28(9):16331638. https://doi.org/10.3174/ajnr.A0682 PMID: 17893219

[11] Hakan T, Kılıç Y, Çelikoğlu E, Ekemen S. An unusual schwannoma in the proximal forearm: a case report. Cureus, 2019, 11(11):e6231. https://doi.org/10.7759/cureus.6231 PMID: 31890430 PMCID: PMC6935331

[12] Siqueira MG, Martins RS, Teixeira MJ. Management of brachial plexus region tumours and tumour-like conditions: relevant diagnostic and surgical features in a consecutive series of eighteen patients. Acta Neurochir (Wien), 2009, 151(9):10891098. https://doi.org/10.1007/s00701-009-0380-8 PMID: 19448970

[13] Galbiatti JA, Milhomens GRDS, Bertozzo LG, Escames L, Milhomens Neto PA, Galbiatti MGP. Retrospective analysis of 20 patients affected by schwannomas in the upper and lower limbs. Rev Bras Ortop (Sao Paulo), 2020, 55(5):629636. https://doi.org/10.1055/s-0040-1702962 PMID: 33093729 PMCID: PMC7575399

[14] Zhu W, Mao Y. Cystic vestibular schwannomas: surgical considerations and outcomes. World Neurosurg, 2015, 83(5): 742-743. https://doi.org/10.1016/j.wneu.2014.09.008 PMID: 25219582

[15] Belli E, Becelli R, Matteini C, lannetti G. Schwannoma of the mandible. J Craniofac Surg, 1997, 8(5):413-416. https://doi. org/10.1097/00001665-199708050-00015 PMID: 9482084

[16] Feijó ED, Nery AC, Caiado FR, Prehis AM, Limongi RM. Extraconal cystic schwannoma mimicking an orbital dermoid cyst. Arq Bras Oftalmol, 2016, 79(4):258-260. https://doi.org/ 10.5935/0004-2749.20160073 PMID: 27626153 
[17] Pushker N, Khurana S, Kashyap S, Sen S, Shrey D, Meel R, Chawla B, Bajaj MS. Orbital schwannoma: a clinicopathologic study. Int Ophthalmol, 2015, 35(4):481-486. https://doi.org/ 10.1007/s10792-014-9973-1 PMID: 25052540

[18] Young SM, Kim YD, Hwang SS, Woo KI. Orbital schwannoma with atypical presentation. J Craniofac Surg, 2018, 29(3): e224-e226. https://doi.org/10.1097/SCS.0000000000004177 PMID: 29419597

[19] Budu VA, Bulescu IA, Popp CG, Mocanu BC, Mogoantă CA. Vagus nerve schwannoma in the parapharyngeal space: surgical, histological and immunohistochemical aspects. A case report. Rom J Morphol Embryol, 2015, 56(1):273-276. PMID: 25826516

[20] Schultz E, Sapan MR, McHeffey-Atkinson B, Naidich JB, Arlen M. Case report 872. "Ancient" schwannoma (degenerated neurilemmoma). Skeletal Radiol, 1994, 23(7):593-597. https:// doi.org/10.1007/BF00223102 PMID: 7824996

[21] Baderca F, Cojocaru S, Lazăr E, Lăzureanu C, Faur A Lighezan R, Alexa A, Raica M, Vălean M, Balica $N$. Schwannoma of the lip: case report and review of the literature. Rom J Morphol Embryol, 2008, 49(3):391-398. PMID: 18758646

[22] Popovici RM, Cărăuleanu $A$, Costea CF, Florea ID, Scripcariu DV, Mogoş RA, Cheaito A, Tănase AE, Haba RM, Grigore M. Rare retroperitoneal conditions that mimic uterine myoma. Rom J Morphol Embryol, 2020, 61(1):7-14. https:// doi.org/10.47162/RJME.61.1.01 PMID: 32747890 PMCID: PMC7728116

[23] Lee JS, Kim HS, Jung JJ, Han SW, Kim YB. Ancient schwannoma of the pancreas mimicking a cystic tumor. Virchows Arch, 2001, 439(5):697-699. https://doi.org/10.10 07/s004280100492 PMID: 11764392

[24] Ahmadi A, Hirbod H, Cheraghipoor M, Izadi F. Schwannoma of the brachial plexus presented as a neck mass: a case report and review of the literature. Int J Otolaryngol Head Neck Surg, 2015, 4(2):104-107. https://doi.org/10.4236/ijohns.2015.42019
[25] Saito S, Suzuki Y. Schwannomatosis affecting all three major nerves in the same upper extremity. J Hand Surg Eur Vol, 2010, 35(7):592-594. https://doi.org/10.1177/17531934103 69284 PMID: 20719892

[26] Adani R, Tarallo L, Mugnai R, Colopi S. Schwannomas of the upper extremity: analysis of 34 cases. Acta Neurochir (Wien), 2014, 156(12):2325-2330. https://doi.org/10.1007/s00701014-2218-2 PMID: 25223747

[27] Abdelwahab IF, Kenan S, Hermann G, Klein MJ, Lewis MM. Intramuscular myxoma of the left forearm. Bull Hosp Jt Dis, 1993, 53(3):15-17. PMID: 8012261

[28] Yamamoto K, Nishio J, Yano S, Naito M. Solitary schwannoma of the sural nerve: an unusual clinical presentation. Exp Ther Med, 2014, 7(1):90-92. https://doi.org/10.3892/etm.2013.1395 PMID: 24348770 PMCID: PMC3861236

[29] Nimura M. Neurofibromatosis (3). Rinsho Derma (Tokyo), 1973, 15:653-663.

[30] Hulsebos TJM, Plomp AS, Wolterman RA, RobanusMaandag EC, Baas F, Wesseling P. Germline mutation of INI1/SMARCB1 in familial schwannomatosis. Am J Hum Genet, 2007, 80(4):805-810. https://doi.org/10.1086/513207 PMID: 17357086 PMCID: PMC1852715

[31] Trăistaru R, Enăchescu V, Manuc D, Gruia C, Ghiluşi M. Multiple right schwannoma. Rom J Morphol Embryol, 2008, 49(2):235-239. PMID: 18516332

[32] Desai KI. The surgical management of symptomatic benign peripheral nerve sheath tumors of the neck and extremities: an experience of 442 cases. Neurosurg, 2017, 81(4):568-580. https://doi.org/10.1093/neuros/nyx076 PMID: 28475798

[33] Cuenca-Martínez F, Grande-Alonso M, Suso-Martí L, La Touche R. Therapeutic exercise based on biobehavioral approach for the rehabilitation of a radial nerve injury after surgical removal of a schwannoma: a case report. J Exerc Rehabil, 2019, 15(4):628-635. https://doi.org/10.12965/jer. 1938372.186 PMID: 31523688 PMCID: PMC6732548

\section{Corresponding author}

Anca Sava, Professor, MD, PhD, Department of Morpho-Functional Sciences I, Grigore T. Popa University of Medicine and Pharmacy, 16 University Street, 700115 laşi, Romania; Phone +40744-303 678, e-mail: dr.anca.sava.68@gmail.com

Received: July 15, 2020

Accepted: February 10, 2021 